\title{
Museology from within. Thinking critically through and with museums
}

\section{LOTTEN GUSTAFsSON REINIUS}

"The museum is a fantastic piano to play upon", a former colleague once stated. By summing up in one sentence that sparky potential of a node where collections and professions, audiences and performances meet, he inspired me to accept a short project at the Museum of Ethnography in Stockholm. My interests have since kept me crisscrossing between museums and the academy. At times I have feared being taken into the mountain for good. To be bergtagen (in Swedish) implies being drawn into the world of troll's: a realm of enchantment and richness where proper sense of time and identity is easily at loss. Eventually I have come to deny any clear-cut divide between my engagements in the field; as curator and researcher.

Similar convictions and ways of working are characteristic of an emergent current in new and critical museology. In the following I will exemplify and discuss what I suggest to term museology from within (cf. Gustafsson Reinius, Silvén \& Svanberg 2012:104; Gustafsson Reinius 2017:74): contributions to the field of critical heritage studies that stay in touch with the public and interior work of museums. It builds on the dialectics of critical distance as well as critical proximity. On a bold day, you might think of it as a synthesis.

In recent years, there has been a notable return to objects and collections, inspired by the so-called material turn in social sciences and the following archival turn in contemporary art. Apart from the ongoing documentation of collections at museums, in depth studies of differing cultural and historical contexts, where objects and archives are used as source material, have been carried out, for instance at Swedish museums of cultural history (cf. Svensson 2005; Sennerfeldt \& Forsberg 2014). Today's museum scene also nourishes from impulses of new participatory strategies and artistic research which have led to esthetically experimental, subjective, and critical investigations of the ways of ordering and exhibiting. Today, collections and audiences are activated in several ways, both by permanent staff as well as through residencies. In an overview, focusing on state funded museums in Sweden (Svanberg 2011), there are examples as different as public archeology on remnants of 19th century world fairs and multi-disciplinary and multiprofessional seminars, where the role of powerful and sacred objects in museums was negotiated for the benefit of exhibition work as well as scholarly debate (Heliga ting 2011).

Since the 1990s, at least, post-colonial reflection and the crises of representation have reached right into the praxis of museums. Targeting exhibitions and collections alike as vehicles for dissemination of hegemonic and colonial world views, these pivotal debates have been followed by a virtual flood of critical analysis in their wake. Whereas some 
have been deeply helpful, others suffer from superficial and repetitive argumentation.

In a recent dissertation about the ways in which differing democratic ideals have materialized over the years in the Historical museum in Stockholm, ethnologist Britta Zetterström Geschwind (2017), sheds new light on meaning production at the very margins of the public spaces, for commerce, entrance, and children's activities. Tellingly, her analysis has demanded a broad use of material, including interviews with staff, archival documentation, and auto ethnographic observations. Being in close relation with internal museum work is often a necessity for finding, for example, relevant categories of archival material and connections between these. But such an active engagement also prevents presumptions of museums as monolithic engines of representation (cf. Gustafsson Reinius 2008:73ff).

Similar premises inspired the joint initiative of a research program, The Sociomaterial Dynamics of Museum Collections (Gustafsson Reinius, Silvén \& Svanberg 2012) that featured three autonomous research projects carried out at central Swedish museum, all analyzing turning points in practices in relation to processes of cultural change. Research on topics such as the treatment of human remains in collections (Svanberg 2015), the construction of Sami heritage (Silvén 2016) and the ritual and reconciliatory aspects of repatriation (Gustafsson Reinius 2017), highlighted the role of mobility in the negotiation and transformation of categories and social relations and demonstrated the relevance of investigations from within.

Reflection and practice in museums depend on each other. Projects such as the mentioned contribute to the understanding of practice, in ways that benefit from what you might call a critical proximity to the object of study. There are also examples of critical and self-reflexive projects at museums that are even more integrated in the public work of the museum machine. Museology from within is as likely to find its research questions through dialogues with stake holders or while tampering with ethical dilemmas in relation to a varied audience, as it is to disseminate and use its findings through public outreach and curation. We are talking about studies that remain close not only to archives and collections, but to exhibitions and audiences as well, thus defying in its very nature the false dichotomies between work for change and the continued production of new knowledge.

Mattias Bäckström (2017) has recently argued that the process of exhibition production is a way to conduct research within museum, a form of knowledge production that depends on the cunning weaving of multidisciplinary dialogue with a more material making of public expression. In this context it might be interesting to note a development of co-produced exhibitions, that set out to revisit collections and exhibitions, through joint and public exploration, informed by critical analysis. Anne Folke Henningsen (2016:172ff) has taken interest in the work on ethnographic museums and exhibitions and the growth of reflexive exhibition systems. An example given is Fetish Modernity (Bouttiaux \& Seiderer 2011; cf. Ferracuti, Frasca \& Lattanzi 2013) which was a travelling exhibition and the result of self-critical curation by six European museums of ethnography within the EUfunded network RIME. Cooperating with artists and determined to show tokens of cultural hybridity in their collections they wanted to move beyond imaginations of an allegedly western modernity. Ten years earlier the project Difficult Matters/Svåra saker 
152 (Silvén \& Björklund 2006) ended its ambitious and strongly self-reflexive investigation of dark and problematic memories within museum collections, with a travelling field station where visitors could contribute personal tokens and narratives. A more recent example is the project History Unfolds at the Historical museum in Stockholm, which brought together researchers, museum curators and artist in an investigation of the interplay of memory and oblivion, ending in a major exhibition and a publication (Larsson Pousette 2017).

An outline as brief as this admittedly runs the risk of becoming narrow in its empirical scope. I am aware that the choice of examples have been rather self- and Stockholmcentered. What I aim to capture is not a unified school of thought but examples that share the potential of proximity to its object of study and activity. Weather this outline is to be read as a belated and utopian manifesto or as a productive methodological direction forward is a judgement left for the reader.

\section{LITERATURE}

Bäckström, Mattias 2016. Att bygga innehåll med utställningar. Utställningsproduktion som forskningsprocess. Lund: Nordic Academic Press.

Bouttiaux, Anne-Marie \& Anna Seiderer, Anna (eds.). 2011. Fetish Modernity. Brussels: Royal Museum for Central Africa, Tervuren.

Ferracuti, Sandra, Elisabetta Frasca \& Vito Lattanzi (eds.). 2013. Beyond Modernity. Do Ethnography Museums Need Ethnography? Rom: Espera Libreria Archeologica.

Folke Henningsen, Anne 2016. "Musealiserade temporaliteter. Tidslighet, tidslöshet och teleologi i etnografiska utställningar." In Johan Hegardt \& Trond Lundemo (eds.). Historiens hemvist. Minne, medier och materialitet. Göteborg \& Stockholm: Makadam, 165-188.
Gustafsson Reinius, Lotten 2008. "Innanför branddörren. Etnografiska samlingar som medier och materialitet." In Solveig Jülich, Patrik Lundell \& Pelle Snickars (eds.). Mediernas kulturhistoria. Mediehistoriskt arkiv 8. Stockholm: Statens ljud och bildarkiv, 73-95.

Gustafsson Reinius, Lotten 2017. “The Ritual Labor of Reconciliation”. Museum Worlds 5. Special issue on Repatriation and ritual. Oxford \& New York: Berghahn Pres, 74-87. doi:10.3167/ armw.2017.050108

Gustafsson Reinius, Lotten, Eva Silvén \& Fredrik Svanberg 2012. "The Sociomaterial Dynamics of Museum Collections". Nordisk Museologi 2, 97-106.

Heliga ting (Sacred Things). I det postsekulära samhället 2011. doi: http://www.varldskulturmuseerna.se/ forskning-samlingar/forskning/publicerat/heligating/

Larsson Pousette, Helene (ed.). 2017. History Unfolds. Contemporary Art Meets History. Stockholm: Historiska museet.

Sakernas tillstånd (The State of Things). Öppningar mot en världskulturell och metodutvecklande samlingsanalys, 2011. doi: http://www. varldskulturmuseerna.se/forskning-samlingar/ forskning/publicerat/sakernas-tillstand/

Sennerfeldt, Karin \& Anna-Maria Forsberg (eds.) 2014. Fråga föremålen. Handbok till historiska studier av materiell kultur. Lund: Studentlitteratur.

Silvén, Eva 2016. "Hemfört, bortfört, återfört: museerna och det samiska kulturarvet”. In Johan Hegardt \& Trond Lundemo (eds.). Historiens hemvist. Minne, medier och materialitet. Göteborg \& Stockholm: Makadam, 189-217.

Silvén, Eva \& Anders Björklund (eds.) 2006. Svåra saker. Ting som upprör och berör. Stockholm: Nordiska museets förlag.

Svanberg, Fredrik (ed.). 2011. Forskning vid museer. Stockholm: Statens historiska museum. Svanberg, Fredrik 2016. Människosamlarna. 
Anatomiska museer och rasvetenskap i Sverige ca

1850-1950. Stockholm: Statens historiska museum.

Svensson, Birgitta (ed.) 2005. Föremål för forskning.

Trettio forskare om det kulturhistoriska

museimaterialitets möjligheter. Stockholm:

Nordiska museet.

Zetterström Geschwind, Britta 2017. Publika

museirum. Materialiseringar av demokratiska ideal

på Statens Historiska Museum 1943-2013. PhD

thesis Stockholms universitet.

Lotten Gustafsson Reinius, Ph.D., Associate

Professor

Visiting Hallwyl professor of ethnology,

Stockholm University and Nordiska Museet

lotten.gustafsson.reinius@nordiskamuseet.se

Nordiska Museet, Box 27820

SE-115 93 Stockholm, Sweden 